\title{
Impact of HRM Practices on Social Performance: Mediating Role of both Satisfaction and Affective Commitment in Multicultural Context
}

\author{
Soumia BENBAHIA \\ Ph.D. Student \\ National School of Trade and Management, ENCG \\ Agadir, Morocco \\ Omar RAJÂA \\ Professor \\ National School of Trade and Management, ENCG \\ Agadir, Morocco
}

\begin{abstract}
Developing organizational commitment and employee satisfaction is one of the major objectives of both big companies and SMEs. The purpose of this paper is to demonstrate how human resources management practices HRMP, can help to have engaged and satisfied employees in their work, and how these human resources attitudes can influence the social performance in the organization. A relationship explained on the basis of social exchange theory and realized through employee survey case study among staffs of a Chinese international group operating in Morocco. The objective is to study the correlation between HRM practices, affective commitment, satisfaction and social performance which was measured by the variables of individual performance, absenteeism and intention to quit in a multicultural context. The results of the analysis reveal that implemented HRM practices influence employee affective commitment partially, and influence their satisfaction significantly and positively. The study exposed also the link between those variables, while highlighting the factors that impact them, such as working conditions, lack of training and insufficient or incomplete personal understanding.
\end{abstract}

Keywords: HRM Practices - Affective Commitment - HR Satisfaction - Social Performance - Multicultural context

\section{Introduction}

The implementation of HRM practices produces, first and foremost, directly results on the company's Human Resources (in terms of attitudes, behavior, skills). Secondly, their model allows a glimpse into the integration of the human links in a causal chain of success made up of several levels of intervention, through a model described as the "Staircase Model" (Le Louarn and Gosselin 2000, Le Louarn and Wils, 2001). This reasoning therefore recognizes that HRM practices have a direct impact on workplace behaviors and attitudes, through indicators such as organizational involvement, similar to the concept of "citizenship behavior" (Tsui et al. 1997) or "commitment" (Mayer \& Schoorman, 1992). This study is at the crossroads of two disciplinary fields that are particularly active today. The first is strategic management of human resources and the second is social exchange (Blau 1964) which examines how, under a principle of social exchange, employees react to the activities provided by HR managers. The purpose of this article is also to provide a review of the literature on the relationship between employee attitudes and social performance, and how this link is evaluated in a foreign company operating in a Moroccan context.

\section{Review of the literature}

\subsection{Effects of HRM practices on different variables}

The impact of HRM Practices on performance is generally related to variations on employee attitudes and behaviors. To explore this relationship, researchers examined and introduced several variables such staff turnover rate (Batt, 2002, Huang, 2000) and absenteeism. Some subjective indicators are also introduced in those links, such as job satisfaction (Guest, 1999), commitment (Tsui et al., 1997) and trust in management (Whitener, 2001). The general modeling of interactions developed by Le Louarn and Wils $(2001,2006)$ allows us to model the links and interactions between those variables. Indeed, their research specifies three levels of employee contributions to the success of the organization:

* First, the contribution of Human Resources in term of inputs, produced by skills and knowledge

* Second, the contribution of managers at the management level, particularly through practices, policies and processes. 
* The third contribution affects human results in terms of attitudes and behaviors. It is precisely this direct relationship between HRM practices and the HR attitudes (affective commitment and satisfaction) and indirect results between HRM practices and social performance, that we will study, based on various works that have been developed. In this regard, we can mention the study conducted by Way (2002) which shows that companies who rely on highperformance HRM practices (communication, remuneration, recruitment, training, employment relationship and teamwork) have more chance to get an increase in productivity and a decrease in turnover. In this study, only remuneration practice had a significant effect on performance measurement. For Guérin, Wils and Lemire (1997), the implementation of participatory and communication-based practices had the effect of substantially reducing the level of employee's job dissatisfaction. This last interpretation is shared by Wiersma and Berg (1999), who related levels of employee's satisfaction in the steel sector with the presence of HR practices of autonomous work groups, training and multiplication of communication channels. Finally, according to Huselid (1995), and Huselid, Jackson and Schuler (1997), there is a strong relationship between the level of investment attained in some innovative HRM practices, and various performance measures such as turnover, level of productivity and economic performance value of the firm.

\subsection{HR results: HRMPs as a vector of attitudes and HR behaviors}

Human Resources Management practices refers to policies and procedures involving HR aspects related to management, planning, recruitment, selection, training and development, performance evaluation and labor relations (Dessler, 2008). In addition, Buddress et al. (2000) define HRMPs as the organizational assets that help an organization maintain the effectiveness of its HR. HRMPs are thus perceived as an important instrument for changing the attitude, behavior and satisfaction of employees, and especially their organizational commitment. Similarly, and according to Noe, Hollenbeck, Gerhart, and Wright (2007), HRM practices are the composition of policies, procedures, and regulations that determines employee attitudes, behaviors, and performance.

In this perspective, the participatory management conceptual model of Lawler et al. (1993) which were inspired from strategic human resources management, suggests four bundles or practices that can increase organizational commitment and employee performance. Information sharing, skills development, power sharing and recognition systems would thereby, influence both organizational commitment and individual performance level.

\subsection{Highlighting the link between HRM practices and organizational commitment}

Affective commitment is one of the most desired attitudes within an organization. A concept that define the extent to which an employee can identify himself with the business and increase his level of emotional attachment and level of participation (Allen and Meyer 1990, Meyer and Allen 1991). Several studies have investigated the association between HRM practices and affective commitment, particularly in correlation with information sharing, which is the basis of HR engagement (Lawler et al., 1992, Rondeau et al.). Other studies have also exposed direct relationships between these two variables, like Dorenbosch et al. (2006), who showed that employee perceptions of coherent HRM practices were positively related to affective commitment to the organization.

In this perspective, Gruman \& Saks (2011) proposed a model of the relationship between HRMPs and employee commitment to improve organizational performance. According to this model, the overall management process can affect employee commitment. Similarly, Suan and Nasurdin (2014) state that the process of rigorous training, rewards, and performance evaluation enhances employee motivation and helps them improve their performance. Accordingly, a link between human resource management practices and employee commitment can be theorized.

\subsection{Highlighting the link between HRM practices and satisfaction}

Whether in theory or in practice, it is almost impossible to assume that employees have the same needs (Kinnie et al., 2005). Employee satisfaction can be seen as an important predictor of behavior, if employees work unreservedly and produce optimally for the organization, it depends in large part on how they feel about their work and organization (Scott et al., 1994). Researchers have suggested that appropriate human resource management practices create positive employee satisfaction and psychological well-being that can motivate employees to achieve organizational goals (Becker et al., 1998). HRMPs correspond in this case to the employee management process that achieves organizational objectives (Wright and Snell, 1991). Other researchers have defined some HRM practices as highly engaged organizational practices like for example compensation, training, employee participation, selectivity and flexible work arrangements designed to motivate employees to succeed at an organizational level (Delery\& Shaw, 2001).

In addition, investing in HRM practices is supposed to reinforce the sense of commitment to the organization and consequently increase employee motivation to support the effectiveness and performance of the organization (Lee and Bruvold, 2003). 


\subsection{Performance as a result of employee attitudes}

Simard et al. (2005) state that people who are emotionally attached to the organization would perform better. Affective commitment would therefore be associated with more positive attitudes to work and a stronger propensity to adopt citizenship behaviors towards the organization (Riketta, 2002). Previous research has shown, however, that affective commitment has an impact on individual work performance, turnover, prosocial behavior and absenteeism (Cohen, 2003).

Two main studies evaluated the effect of HRMPs on HR behaviors based on the theory of human capital and the efficiency of employees. Mudor \& Tooksoon, (2011) conclude based on their study results that satisfaction is significantly correlated with HR behaviors, while HRM practices were able to improve satisfaction and performance.

The classic approach to this issue is often to analysis the relationship negatively, highlighting the costs of high rates of turnover, absenteeism, or low work performance. Another way to study the issue is to consider a more positive approach of the "happy productive worker" which consider that engaged and satisfied employee by the HRM practices implemented in his company would necessarily be an effective employee. Furthermore, Harter and al. (2002) state of a significant correlations between overall performance satisfaction and commitment. This study reveals the effects of satisfaction and commitment on staff turnover, customer satisfaction and loyalty, as well as on the number of work accidents. Finally, Allen, Shore, and Griffeth (2003) have shown that perceived organizational support is positively associated with job satisfaction and organizational commitment. According to the same study, organizational commitment negatively influences the turnover as an outcome. Indeed, hired employees would be less absent and more loyal to their organization (Meyer \& al., 2002), more willing to make efforts, perform at work and adopt citizen behaviors (Becker \& Keman, 2003; \& al, 2002, Podsakoff et al., 2000).

\section{Theoretical framework mobilized:}

\subsection{Theory of social exchange}

The theory of social exchange (Blau 1964) is an approach in which the relation to organization can be conceptualized as including economic and social exchanges (Aryee et al., 2002). Economic exchanges are based on contractual arrangements, requiring the fulfillment of specific obligations with no expectation of performance that falls beyond the terms of the contract. Rather, social exchanges, involve specified terms and are based on the standard of reciprocity which suggests that people feel obliged to give back to those who gave them (Tzafrir, 2005).

The theory of social exchange suggests that when employees perceive equity in the way they are treated by their organizations, they will exchange positively (Aryee et al., 2002). This theory thus explains how employee attitudes and behaviors are modified under the influence of certain HRM practices (Chang and Chen, 2011, Wu and Chaturvedi, 2009) and how these behaviors are strategically important to improve organization performance (Collins and Smith 2006; Sun and al. 2007).

Indeed, HRM Practices can be seen as an important contribution to the social exchange process, by which employee perceptions, attitudes and behaviors are shaped (Kuvaas, 2008). Thus, a bundle of HRM practices would create positive exchange relations, which would consequently encourage the participation of human resources in the development of organizational performance.

In other words, the use of HRM practices can contributed to demonstrate, that the organization is committed to its employees, is concerned about their well-being and development, and wants to invest in them. Through practices like those of training and development, performance appraisal, identification of training needs, performance-based compensation, employee involvement in decision-making processes, and communication about organizational values.

\subsection{Theoretical support of the mediating role of $H R$ attitudes in the relation between HRMP and Performance}

Searchers and practitioners have increasingly recognized the importance of effective human capital management for organizational performance (Grant 1996, Hitt, Biermant, Shimizu and Kochhar 2001). This claim is supported by extensive field research (Delery\& Doty 1996, Huselid 1995, MacDuffie 1995) and subsequent confirmatory and metaanalyzes (Combs et al., 2006, Wright et al., 2005). Several empirical studies confirm that effective HR practices have an immediate effect on employee attitudes and behaviors, such as job satisfaction, affective commitment (Gong et al., 2009, Takeuchi et al., 2009), turnover (Sun et al., 2007) and social exchanges (Takeuchi, Lepak, Wang and Takeuchi, 2007). Further, theoretical studies about the causal chain of HR performance suggest that these studies may explain the relationships between human resource practices and employee outcomes (Bowen and Ostroff 2004, Nishii and Wright 2008). Empirical studies have also shown that employee's perceptions about human resource management practices differ significantly from the perception of top management and HR managers (Liao et al., 2009). 
According to Fabi, Lacoursière, and Raymond (2015), the usage of HRM practices that improve working conditions would encourage positive attitudes among employees and have an impact on HR behaviors. Boselie, Dietz, and Boon (2005) and Gerhart (2005), suggest that grouping practices in bundles would improve satisfaction directly (Wu and Chaturvedi, 2009) and generate a positive association with organizational commitment (Guchait et al. Cho, 2010; Meyer and Smith, 2000) and a negative correlation with intention to quit (Jiang et al., 2012). The literature clearly suggests that human resources attitudes have significant correlation with performance and that human resource management practices can affect individual employee performance through their influence on job satisfaction and employee commitment, through structures that enable employees to improve the way their jobs are done (Huselid, 1995). This motivation process helps to link job to both organizational and individual results through employee commitment.

In our study, we will analyze the perceived influence of HRM practices on employee satisfaction and commitment in the affective dimension and finally on social performance. Inspired by different models of HRM practices combinations, we propose to analyze the perceived influence of communication practices and participation, integration and organization of work, training and development, remuneration and recognition, career management and job security, on satisfaction and affective commitment and also on the social performance.

Based on what we exposed previously, the conceptual model of the research is presented in the following figure:

Fig 1: Conceptual model of the study

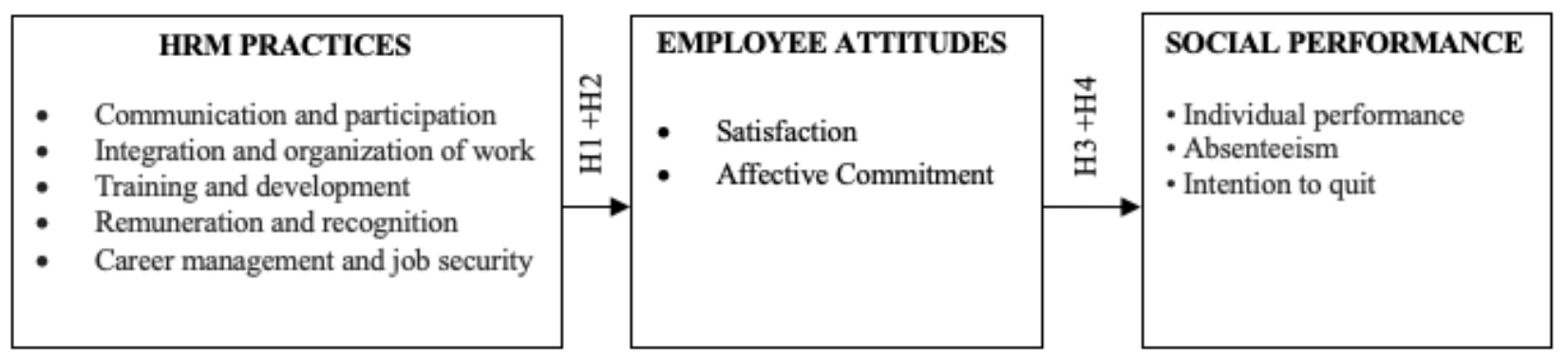

Source: Elaborate by ourselves

Both the theoretical base and the results of the empirical studies that we have just presented, suggest a significant effect of HRM practices on the social performance of organizations, through the satisfaction and commitment of its employees as mediated variables. Indeed, our hypothesis concerned two parts of this correlation. The first examines the antecedents of employee attitudes in terms of satisfaction and affective commitment, and the second, states a relationship between these attitudes and social performance. All of the literature consulted leads us to develop the following four hypotheses:

H1: Human resource management practices related to communication and participation, integration and organization of work, training and development, remuneration and recognition, career management and job security, support HR satisfaction

H2: Human resource management practices related to communication and participation, work integration and organization, training and development, remuneration and recognition, career management and job security, support affective commitment of employees

H3: HR satisfaction is significantly and positively correlate to the social performance

H4: Affective commitment is significantly and positively correlate to the social performance

\section{Methodology}

Case studies can analysis a phenomenon in detail, reach a high level of conceptual validity, and can help to develop new hypotheses (George \& Bennett, 2005). This research strategy fits with the objectives of our study, as we want to improve understanding of the attitudes of employees resulting of the implementation of certain HRM practices, including their satisfaction and their affective commitment in the model of correlation. The data was collected using a structured survey, distributed to staff of a Chinese energy equipment and electrical equipment company operating in Morocco with more than 145 Moroccan employees. A total of 120 questionnaires were distributed directly to employees at their work place. 59 questionnaires were collected, representing a response rate of $49.17 \%$. 


\subsection{Human resource management practices measurement}

Measurement instrument developed to measure HRM practices includes several items grouped into five HRM practice categories that have demonstrated significant relationships with job satisfaction, organizational commitment and social performance in different empirical studies. The formulation of items was inspired by the literature (Tremblay et al, 2000, Trudel et al, 2005). These categories of practices are related to communication and participation, work integration and organization, training and development, compensation and recognition, career management and job security.

A Likert Scale is a type of rating scale used to measure attitudes or opinions. With this scale, respondents were asked to rate items on a level of agreement for each of HRM practices. Participants were asked to indicate their level of agreement with each statement asking for implementation of practices in their organization and HR services, using a five-point Likert-type scale from strongly disagree (1) to strongly agree (5). Items like: "The organization ensures the reception and support for the integration of new hires" (Integration), "In the organization where I work, my salary is influenced by my results" (Remuneration), etc., have been suggested in the questionnaire submitted to employees.

\subsection{Measurement of satisfaction, affective commitment and social performance}

Job satisfaction was measured using also five points Likert scale ( $1=$ very dissatisfied and $5=$ very satisfied) from the shorter version of Weiss's Minnesota Satisfaction Questionnaire (MSQ), Dawis, England \& Lofquist (1967). Commitment was evaluated according to affective dimension, representing the emotional attachment and the identification of an employee towards his organization. It was measured using a modified version of Meyer's organizational commitment scales, Allen \& Smith (1993). In accordance with our theoretical model, social performance was measured though three variables: individual performance, absenteeism and intention to quit. Each variable was measured through two items.

\section{Results}

In the following, we will present and discuss the results of descriptive analysis and multivariate analyzes, evaluated using SPSS 16.0 software to test the research hypothesis.

\subsection{Results of the descriptive analysis}

Before proceeding to the actual results, it seems necessary to present certain characteristics of the respondents. The sample consists of $67 \%$ men versus 33\% women. More than $75 \%$ of respondents are between 25 and 34 years old and $23 \%$ are under 25 years old. Regarding the level of studies, 38\% have a level of studies of engineer, 37\% have a level of university degree, $15 \%$ have a level of Master degree, $7 \%$ have a level of DUT, while 2 of the interviewed employees have a level higher than Master degree. Finally, additional data provide information on the seniority, family situation. The status of respondents is distributed on $43 \%$ of managers and engineers, $23 \%$ of senior technician, $17 \%$ of agents of mastery, $12 \%$ of Technician and $5 \%$ of various positions.

According to the descriptive results of the average perception that employees have of HRM practices implemented in the company, the integration and work organization practices registers an average of $(2,41 / 5)$ and communication and participation registers an average of $(2,29 / 5)$, and can be considerate as those who have a positive and significant perception comparing to the other practices. While the training practice $(1.96 / 5)$ is the one that seems least well perceived by employees. The analysis of descriptive data (mean and standard deviation) on variables related to HRM practices reveals higher average values for the two practices of integration and organization work and also for communication and participation. Practices of training and development relate however with the lowest average value. For satisfaction variables, affective commitment, individual performance, absenteeism and intention to quit, the averages of these variables are higher.

\subsection{Results of correlation and regression analysis}

From the results obtained, we can note that the significant correlations are between 0.10 and 0.53 , none of these correlations exceeds 0.75 , a threshold from which the problem of multicollinearity intervenes (Chen \& Francesco, 2003). The relationships between the variables involved in the research hypotheses represent weak relationships for those linking HRM practices to affective commitment and HRM practices to individual performance. However, the correlation seems high, concerning the relationship between HRM practices and satisfaction (.27 r .53).

The correlations between the independent variables of HRM practices and satisfaction, represent the highest and most significant level of correlation, as well as the correlation between the human resources satisfaction and the individual performance variable. The correlation results show also a strong link between satisfaction and all HRM practices from $(0.420 * *)$ for remuneration practices to $(0.534 * *)$ for integration and work organization practices, with a less important correlation for training and development practice $(0.277 *)$. 
Regarding to individual performance, it seems to have a significant correlation only with the integration and work organization practices $\left(0.268^{*}\right)$ and communication and participation $\left(0.207^{*}\right)$. Absenteeism is negatively correlated with the three practices of integration and organization of work, communication and participation and career management and job security with respective correlations of $\left(-0.246^{*}\right),\left(-0.211^{*}\right)$ and $\left(-0.214^{*}\right)$. A significant correlation found between absenteeism and the "age" variable. Finally, the intention to quit seems to be strongly correlated with the status of the employee in the company $\left(0.392^{* *}\right)$ and the three practices of training and development with a correlation of $\left(-0.371^{* *}\right)$, remuneration and recognition practices $\left(-0.236^{*}\right)$ and career management practices and job security $\left(-0.255^{*}\right)$. However, the other practices do not show significant correlations with the dependent variable of intention to quit.

The first hypothesis stipulating a positive relationship between HRM practices and satisfaction was tested with a simple regression analysis, and the results allow us to validate the hypothesis of the relationship between these two variables with an adjusted $\mathrm{R}^{2}$ of 0.28 .

The second hypothesis supposing a positive relationship between HRM practices and affective commitment was tested with a simple regression analysis. However, the results show that there is no relationship between these two variables, as emphasized by the weakness of the adjusted $\mathrm{R}^{2}(-0.024)$ and the lack of significance of the ANOVA model. HRM practices do not seem to have an impact on affective commitment for the model and population studied. Thereby, the hypothesis $\mathrm{H} 2$ is not validated.

The third hypothesis that asserts a positive relationship between satisfaction and social performance was tested with a simple regression analysis. The results show a positive relationship between these two variables with an adjusted $\mathrm{R}^{2}$ of (0.149), which highlights a significant impact of satisfaction on individual performance. As for the relationship of satisfaction with the other two variables of social performance (absenteeism and intention to quit). A correlation seems to exist between these variables but with a modest adjusted $\mathrm{R}^{2}$ of $(0.099)$ for absenteeism and $(0.045)$ for intention to quit, significantly lower than that observed for satisfaction and performance, which allow us, only partially validates this third hypothesis.

The fourth hypothesis, which suggests a link between affective commitment and social performance, was tested with a simple regression analysis, the results show a very weak correlation between these two variables with a respective adjusted $\mathrm{R}^{2}$ of $(0.02)$ for individual performance, $(-0.009)$ for absenteeism and $(0.001)$ for intent to quit. These results do not validate the hypothesis of the impact of the affective commitment on absenteeism, and only partially validates it in terms of individual performance and intention to quit.

This result can be explained by the average age of respondents and the seniority of all employees, which is less than two years. Adding to this, the intercultural context that characterizes the company can also explain some results. Finally, a multiple regression analysis was conducted with a step-by-step entry, and allow us to confirm that satisfaction variable has the highest degree of impact on social performance and more specifically on individual performance in the two models emerging from the analysis, (adjusted $\mathrm{R}^{2}$ of 0.164 and 0.176 ). The variable of affective commitment is excluded from the first model but reintegrated in the second, allowing the $\mathrm{R}^{2}$ to progress slightly.

\section{Discussion and Conclusion}

The existing literature about employee commitment and satisfaction, reveals that they are designed in different ways within organizations. There is no consensus in their definitions and so have a multi-faceted construct (Kahn, 1990). This study suggests that a committed and satisfied employee is someone who is optimistic, motivated, efficient, and ready to contribute to organizational success in the long term. This article allows, thanks to the theoretical and empirical approach, to deepen knowledge on the effects of the perception of HRM practices. Our goal is to empirically study the respective influence of employee satisfaction and affective commitment toward human resource management practices, on social performance by collecting data directly from employees not from HR manager.

Apart from testing the staircase model of Le Louarn \& Wils (2001) based on the theory of social exchange, results of this study show the strategic nature of HRM in the success of organizations. HRM practices appear to be important levers of social performance and that they clearly affect HR satisfaction and their affective commitment.

Therefore, companies should direct their management towards the well-being of employees to build an appropriate human resources policy. The study allowed us to detect among the practices studied, those that more influenced the satisfaction and commitment of employees. Through our results, and in addition to the variables of our model, the factors of working conditions, lack of training, work environment and the non-consideration of personal constraints seem to be the most influential factors respectively. Also, the satisfaction of overcoming and the challenges and the desire to satisfy the customers are factors influencing the degree of investment in the work of the interviewed employees. 
The choice of HR practices and their application should be considered with interest, drawing in particular on the results of research in this field, particularly in the Moroccan context, and more specifically for foreign groups and companies that set up their businesses regarding to their cultural and managerial specificity.

Additional more studies can be conducted to explore the way in which this relationship evolves. Research still opens, and it would be interesting to explore further models and incorporate other intermediate variables using structural equation model's analysis which provide more clarity on results. That would certainly help to make decision and increase the level of comprehension of human resources commitment and satisfaction factors that most influence them.

\section{References}

Allen, D. G., Shore, L. M., \&Griffeth, R. W. (2003). The role of perceived organizational support and supportive human resource practices in the turnover process. Journal of management, 29(1), 99-118.

Allen, N. J., \& Meyer, J. P. (1990). The measurement and antecedents of affective, continuance and normative commitment to the organization. Journal of occupational psychology, 63(1), 1-18.

Aryee, S., Budhwar, P. S., \& Chen, Z. X. (2002). Trust as a mediator of the relationship between organizational justice and work outcomes: Test of a social exchange model. Journal of Organizational Behavior: The International Journal of Industrial, Occupational and Organizational Psychology and Behavior, 23(3), 267-285

Batt, R. (2002). Managing customer services: Human resource practices, quit rates, and sales growth. Academy of management Journal, 45(3), 587-597.

Becker, B. E., Huselid, M. A., Becker, B. E., \&Huselid, M. A. (1998). High performance work systems and firm performance: A synthesis of research and managerial implications. In Research in personnel and HRM.

Becker, T.E. and Keman, M.C. (2003) 'Matching commitment to supervisors and organizations to in-role and extrarole performance', Human Performance, Vol. 16, pp.327-348.

Boselie, P., Dietz, G., \& Boon, C. (2005). Commonalities and contradictions in HRM and performance research. Human resource management journal, 15(3), 67-94.

Bowen, D. E., \&Ostroff, C. (2004). Understanding HRM-firm performance linkages: The role of the "strength" of the HRM system. Academy of management review, 29(2), 203-221.

Buddress, Lee and Alan Raedels (2000), "Essential Tools of Supply Chain Management," Hospital Materiel Management Quarterly Review, Vol. 22, No.1, pp. 36-41.

Cohen, A. (2003). Multiple commitments in the workplace: An integrative approach. Psychology Press.

Combs, J., Liu, Y., Hall, A., \&Ketchen, D. (2006). How much do high-performance work practices matter? A meta-analysis of their effects on organizational performance. Personnel psychology, 59(3), 501-528.

Delery, J. E., \& Doty, D. H. (1996). Modes of theorizing in strategic human resource management: Tests of universalistic, contingency, and configurational performance predictions. Academy of management Journal, 802-835.

Delery, J. E., \& Shaw, J. D. (2001). The strategic management of people in work organizations: Review, synthesis, and extension. In Research in personnel and human resources management (pp.165-197).

Dessler, G. (2008), Human Resource Management, Pearson Prenctice Hall 11ème Edition. Colbert, B.A. (2004), « The complex resource-based view : implications for theory and practice in strategic human resource management., Academy of Management Review, vol 29, n³, p. 341-358

Dorenbosch, L., de Reuver, R., \& Sanders, K. (2006). Getting the HR Message Across: The Linkage between Line-HR Consensus and" Commitment Strength" among Hospital Employees. management revue, 274-291.

Fabi, B., Lacoursière, R., \& Raymond, L. (2015). Impact of high-performance work systems on job satisfaction, organizational commitment, and intention to quit in Canadian organizations. International Journal of Manpower, 36(5), 772-790.

Gerhart, B. (2005). Human resources and business performance: Findings, unanswered questions, and an alternative approach. Management revue, 174-185.

Gong, Y., Huang, J. C., \&Farh, J. L. (2009).Employee learning orientation, transformational leadership, and employee creativity: The mediating role of employee creative self-efficacy. Academy of management Journal 765-778.

Grant, R. M. (1996). Toward a knowledge-based theory of the firm. Strategic management journal, 17(S2), 109-122.

Gruman, J. A., \& Saks, A. M. (2011). Performance management and employee engagement. Human resource management review, 21(2), 123-136.

Guchait, P., \& Cho, S. (2010). The impact of human resource management practices on intention to leave of employees in the service industry in India: the mediating role of organizational commitment. The International Journal of Human Resource Management, 21(8), 1228-1247. 
Guérin, G., Wils, T., \& Lemire, L. (1997). L'efficacité des pratiques de gestion des ressources humaines: le cas de la gestion des professionnels syndiqués au Québec. Relations Industrielles/Industrial Relations, 52(1), 61-90.

Guest, D. E. (1999). Human resource management-the workers' verdict. Human resource management journal,5-25.

Harter, J. K., Schmidt, F. L., \& Hayes, T. L. (2002). Business-unit-level relationship between employee satisfaction, employee engagement, and business outcomes: A meta-analysis. Journal of applied psychology, 87(2), 268.

Hitt, M. A., Bierman, L., Shimizu, K., \& Kochhar, R. (2001). Direct and moderating effects of human capital on strategy and performance in professional service firms: resource-based perspective Academy of Management journal, 13-28.

Huang, T. C. (2000). Are the human resource practices of effective firms distinctly different from those of poorly performing ones?. International Journal of Human Resource Management, 11(2), 436-451.

Huselid, M. A. (1995). The impact of human resource management practices on turnover, productivity, and corporate financial performance. Academy of management journal, 38(3), 635-672.

Huselid, M. A. (1995). The impact of human resource management practices on turnover, productivity, and corporate financial performance. Academy of management journal, 38(3), 635-672.

Huselid, M. A., Jackson, S. E., \& Schuler, R. S. (1997). Technical and strategic human resources management effectiveness as determinants of firm performance. Academy of Management journal, 40(1), 171-188.

Jiang, K., Lepak, D. P., Hu, J., \& Baer, J. C. (2012). How does human resource management influence organizational outcomes? A meta-analytic investigation of mediating mechanisms. Academy of management Journal, 12641294.

Kinnie, N., Hutchinson, S., Purcell, J., Rayton, B., \&Swart, J. (2005). Satisfaction with HR practices and commitment to the organisation: why one size does not fit all. Human Resource Management Journal, 15(4), 9-29.

Lawler III, E.E. (1993) « Creating the High-Involvement Organization », in Galbraith, J.R., Lawler III, E.E. and Ass., Organizing for the future, The New Logic for Managing Complex Organizations, Josey-Bass, San-Francisco, pp. 172-93.

Lawler, E. E., Mohrman, S. A., \& Ledford, G. E. (1992). Employee involvement and total quality management: Practices and results in Fortune 1000 companies. Jossey-Bass Inc Pub.

Le Louarn, J. Y., \& Gosselin, A. (2000). GRH et profits: y a-t-il un lien?. Effectif, avril-mai, 18-23.

Le Louarn, J. Y., \&Wils, T. (2001). L'évaluation de la gestion des ressources humaines. Liaisons.

Lee, C. H., \&Bruvold, N. T. (2003). Creating value for employees: investment in employee development. The International Journal of Human Resource Management, 14(6), 981-1000.

Liao, H., Toya, K., Lepak, D. P., \& Hong, Y. (2009). Do they see eye to eye? Management and employee perspectives of high-performance work systems and influence processes on service quality. Journal of applied psychology, 371.

MacDuffie, J. P. (1995). Human resource bundles and manufacturing performance: Organizational logic and flexible production systems in the world auto industry. ILR Review, 48(2), 197-221.

Mayer, R. C., \&Schoorman, F. D. (1992). Predicting participation and production outcomes through a two-dimensional model of organizational commitment. Academy of Management journal, 35(3), 671-684

Meyer, J. P., \& Allen, N. J. (1991). A three-component conceptualization of organizational commitment. Human resource management review, 1(1), 61-89.

Meyer, J. P., \& Smith, C. A. (2000). HRM practices and organizational commitment: Test of a mediation model. Canadian Journal of Administrative Sciences/Revue canadienne des sciences de l'administration, 319331.

Meyer, J. P., Stanley, D. J., Herscovitch, L., \&Topolnytsky, L. (2002). Affective, continuance, and normative commitment to the organization: A meta-analysis of antecedents, correlates, and consequences. Journal of vocational behavior, 61(1), 20-52.

Mudor, H., \&Tooksoon, P. (2011). Conceptual framework on the relationship between human resource management practices, job satisfaction and turnover. Journal of Economics and Behavioral Studies, 2 (2), 41-49.

Nishii, L. H., \& Wright, P. (2008). Variability at multiple levels of analysis: Implications for strategic human resource management. The people make the place, 225, 248.

Noe, R. A., Hollenbeck, J. R., Gerhart, B. A., \& Wright, P. M. (2007). Fundamentals of human resource management.

Podsakoff, P. M., MacKenzie, S. B., Paine, J. B., \& Bachrach, D. G. (2000). Organizational citizenship behaviors: A critical review of the theoretical and empirical literature and suggestions for future research. Journal of management, 26(3), 513-563.

Riketta, M., \&Landerer, A. (2002). Organizational commitment, accountability, and work behavior: A correlational study. Social Behavior and Personality: an international journal, 30(7), 653-660. 
Rondeau, A., Lemelin, M., \& Lauzon, N. (1993). Les pratiques de mobilisation: vers une typologie d'activités favorisant l'implication au travail et l'engagement organisationnel. École des hautes études commerciales. Centrale de cas et de documents pédagogiques.

Scott, S. G., \& Bruce, R. A. (1994). Determinants of innovative behavior: A path model of individual innovation in the workplace. Academy of management journal, 37(3), 580-607.

Simard, G., Doucet, O., \& Bernard, S. (2005). Pratiques en GRH et engagement des employés: le rôle de la justice. Relations industrielles/Industrial Relations, 60(2), 296-319.

Suan, C. L., \&Nasurdin, A. M. (2014). Do human resource management practices affect employees' service-oriented organizational citizenship behavior? Evidence from the Malaysian hotel industry. World Applied Sciences Journal, 31(2), 253-266.

Sun, L. Y., Aryee, S., \& Law, K. S. (2007). High-performance human resource practices, citizenship behavior, and organizational performance: A relational perspective. Academy of management Journal, 50(3), 558-577.

Takeuchi, R., Chen, G., \&Lepak, D. P. (2009). Through the Looking Glass of A Social System: Cross-Level Effects of High-Performance Work Systems on Employees' Attitudes. Personnel Psychology, 62(1), 1-29.

Takeuchi, R., Lepak, D. P., Wang, H., \& Takeuchi, K. (2007). An empirical examination of the mechanisms mediating between high-performance work systems and the performance of Japanese organizations. Journal of Applied Psychology, 92(4), 1069.

Tsui, A. S., Pearce, J. L., Porter, L. W., \& Tripoli, A. M. (1997). Alternative approaches to the employee-organization relationship: does investment in employees pay off?. Academy of Management journal, 40(5), 1089-1121.

Way, S. A. (2002). High performance work systems and intermediate indicators of firm performance within the US small business sector. Journal of management, 28(6), 765-785.

Whitener, E. M. (2001). Do "high commitment" human resource practices affect employee commitment? A cross-level analysis using hierarchical linear modeling. Journal of management, 27(5), 515-535.

Wiersma, U.J. and Van Der Berg, P.T. (1999) 'Influences and Trends in Human Resource Practices in the Netherlands', Employee Relations, 21(1-2): $63-80$

Wright, P. M., \& Snell, S. A. (1991). Toward an integrative view of strategic human resource management. Human resource management review, 1(3), 203-225.

Wright, P. M., Gardner, T. M., Moynihan, L. M., \& Allen, M. R. (2005). The relationship between HR practices and firm performance: Examining causal order. Personnel psychology, 58(2), 409-446.

Wu, P. C., \& Chaturvedi, S. (2009). The Role of Procedural Justice and Power Distance in the Relationship between High Performance Work Systems and Employee Attitudes: A Multilevel Perspective. Journal of Management, 1228-1247. 